\title{
ASSESSMENT OF INDOOR AIR IN ESTONIAN STRAW BALE AND REED HOUSES
}

\author{
JANE RAAMETS, SANDER KUTTI, AIME RUUS \& MARI IVASK \\ Tartu College, School of Engineering, Tallinn University of Technology, Estonia
}

\begin{abstract}
Fungi play an important role in the decomposition process of organic matter. They are able to grow almost in all organic substrates - as well on straw and reed. In Estonia, there is a growing interest in building with green materials due to their low embodied energy and insulation value. The most common understanding is that living in a house built of straw or reed blocks can be also beneficial for human health - people with asthma, allergies and acute environmental sensitivities would suffer less. The aim of this study was to evaluate indoor air in sleeping areas in Estonian straw bale and reed houses. Samples were collected once every season between October 2014 and October 2016, from 8 households ( 4 straw bale houses, 4 reed houses). Occupants were asked not to air the houses $6 \mathrm{~h}$ prior to measurements. For each sample, the corresponding outdoor air was measured as a reference value. In order to determine fungal spore concentrations in the air, Microbio MB2 air samplers were used. Malt extract agar and dichloran glycerol agar plates were used as culture media. The total colony forming units per $\mathrm{m}^{3}$ were determined. The microorganisms were identified from the isolated colonies. The most abundant bacterial and fungal genes isolated from samples were Alternaria, Aspergillus, Cladosporium and Penicillum.

Keywords: straw bale buildings, reed buildings, indoor air, airborne fungi.
\end{abstract}

\section{INTRODUCTION}

To reduce carbon emission and save energy, interest in renewable materials has been increasing [1]. Straw and reed are two of such kinds of materials. Straw is currently produced in surplus to requirements, so it is cheap and easily accessible in most countries [2] as well as in Estonia. Every year approximately $100-150$ tons of straw will be produced as a byproduct [3]. According to Veski et al. [4], reed stands are also common in Estonia: approximately 26,000 ha in total. Thickets of reed produces $10-40 \mathrm{t} /$ ha biomass per year. [4]

Research has shown that straw-bale construction is a sustainable way for building, from the standpoint of both materials and energy needed for heating and cooling [5]. These buildings can be also a potential risk for the human health if not built and ventilated correctly. These main health risks are all linked to the most common microorganisms like Aspergillus, Penicillum, Cladosporium proliferating in damp buildings (Kuhn et al. [6]; Chapman [7]). All mentioned genera of fungi are also known as allergy causers of respiratory system (Singh [8]).

Spores in a dormant state are commonly present in the air and on the surfaces of objects. In this context, air ventilation is an easy and safe method to control and stabilize relative humidity, temperature, moisture content and consequently, microbial activity rate [9].

The goal of this study was to examine sleeping areas in Estonian straw bale and reed houses Spore concentrations of indoor air were compared with spore concentrations outdoors.

\section{MATERIAL AND METHODS}

The assessment of indoor air in straw bale and reed houses was carried out in October 2014October 2016 in the Northern part of Estonia. 
Fungal air sampling was performed four times a year (every season) during a two-year period in sleeping areas of Estonian straw bale $(n=4)$ and reed built households $(n=4)$. Occupants were asked not to air the houses $6 \mathrm{~h}$ prior to measurements.

Microbio MB2 air samplers were used, passing 1001 of air per sample. Sampling time was $1 \mathrm{~min}$. A set of four air samples captured in each area was used to obtain average contamination values and representative results. For each sampling, the corresponding outdoor air was measured as reference value. Sampling was carried out inside $1 \mathrm{~m}$ above floor level and outside $1.5 \mathrm{~m}$ above the ground. The sample plates were incubated at $32^{\circ} \mathrm{C}$ for 72 hours and the colony forming units (CFU) were counted. Malt extract agar (MEA) and dichloran glycerol agar (DG18) plates were used as culture media. The fungal and bacterial colonies were recultivated periodically. All types of growth media were autoclaved at $120^{\circ} \mathrm{C}$ and poured to Petri dishes to dry overnight. The isolated microorganisms were plated with a spatula on the agar plates. The cultures were grown on the petri dishes under $32^{\circ} \mathrm{C}$. All necessary chemicals and reagents (Fluka) were purchased from HNK Analüüsitehnika.

The identification was performed via sample staining and microscopy. Online databases and Bergey's manuals were used.

Evaluation of data was performed with Statistica Version 10.0 (Kruskal-Wallis H-test) and Excel 2010; $p \leq 0.05$ is considered as significant.

\section{RESULTS AND DISCUSSION}

Atmospheric air contains spores of certain fungal species. Depending on the environmental and climatic conditions and living conditions of fungi, spore concentrations in outdoor air can vary.

The seasonal variations in the colony counts for both outdoor and indoor air are shown in Tables 1 and 2. As expected and reported before [10], the maximum concentrations of airborne fungi were recorded during the summer months (June-August). The mean indoor and outdoor concentrations were lower, especially in winter (December-February). We found similar concentrations to each other in spring and in autumn (March-May; SeptemberNovember). Mean values indoors were greater in reed houses. Probably is this so because two of reed houses did not have a decent HVAC system [11].

Table 1: Seasonal variation in culturable airborne fungi indoors shown as mean and in parentheses range of $\mathrm{CFU} \mathrm{\textrm {m } ^ { - 3 }}$ air.

\begin{tabular}{|l|l|l|l|l|}
\hline Sampling site & Winter & Spring & Summer & Autumn \\
\hline Straw bale indoor (MEA) & $149(60-240)$ & $298(110-620)$ & $537(200-840)$ & $307(100-610)$ \\
\hline Straw bale indoor (DG 18) & $14(0-42)$ & $29(10-56)$ & $46(20-88)$ & $20(0-62)$ \\
\hline Reed indoor (MEA) & $380(160-760)$ & $518(200-900)$ & $858(560-1060)$ & $548(120-860)$ \\
\hline Reed indoor (DG 18) & $22(0-60)$ & $23(6-50)$ & $36(11-62)$ & $22(8-51)$ \\
\hline
\end{tabular}

Table 2: Seasonal variation in culturable airborne fungi outdoors shown as mean and in parentheses range of $\mathrm{CFU} \mathrm{m}^{-3}$ air.

\begin{tabular}{|l|l|l|l|l|}
\hline Sampling site & Winter & Spring & Summer & Autumn \\
\hline Straw bale outdoor (MEA) & $94(50-160)$ & $197(120-350)$ & $289(210-380)$ & $168(100-280)$ \\
\hline Reed outdoor (MEA) & $118(80-150)$ & $198(80-310)$ & $353(240-420)$ & $212(140-300)$ \\
\hline Straw bale outdoor (DG 18) & $18(0-42)$ & $30(10-56)$ & $50(20-88)$ & $22(2-54)$ \\
\hline Reed outdoor (DG 18) & $24(8-51)$ & $27(10-58)$ & $45(28-77)$ & $23(8-48)$ \\
\hline
\end{tabular}


There was a very weak $(r=0.38, P<0.05)$ relationship between the house characteristics and the presence of fungal propagules in indoor air. Relative humidity $(r=0.89, P<0.05)$, temperature $(r=0.86, P<0.05)$, season $(r=0.71, P<0.05)$ and pets $(r=0.88, P<0.05)$ inside homes had a statistically significant impact on the presence of fungal propagules in indoor air.

There was no difference between species, which lived in straw bale and reed houses. Outdoor air samples corresponded to indoor ones. The fungal genera identified during this study are common organisms that are regularly present in homes. Some of the species can be harmful to human health by the ability to produce mycotoxins [9].

Most common genus in indoor air during winter was Penicillum, on second place was Aspergillus and then other fungi. In spring the main genus was Cladosporium. We also found fungi from genus Penicillum, Aspergillus, others and Alternaia. In summer was the most abundant genera also Cladosporium. We found other genera - Penicillum and Alternaria as well during the summer time. In autumn was the most abundant Cladosporium, followed by Alternaria, Penicillum, other fungi and Aspergillus. Similar seasonal variations have found earlier by Mędrela-Kuder [10].

Average concentration below 500 allergenic spores in air causes only minor symptoms in persons known to react very strongly to allergenic species. Concentrations above 500 or 600 spores $\mathrm{m}^{-3}$ induce symptoms of disease in all who suffer from allergy [10].

The fungal kingdom is thought to contain over a million species. About 600 of them cause some form of human disease [12].

In most cases the species of genus Alternaria are either obligate or facultative pathogens. It has been estimated that about $70 \%$ of atopic sensitive peoples respond to the presence of Alternaria spores in air samples [7], [13], [14].

Species of genus Aspergillus can cause severe invasive infections in most of major organ system. Aspergillus most commonly infects immunocompromised hosts in the respiratory tract [7], [15], [16].

The genus Cladosporium has different species, from plant to human pathogens. Most of the species of this genus produce a very distinctive and obnoxious odour (chemical compounds responsible for odour are considered toxic) by what it can be easily identified [16]. Some of these species can cause inflammation of the respiratory system as well as inflammation of eyes and skin as well asthma [8], [16], [17].

The species of the genera Penicillium are the most abundant considering spores in outdoor and indoor air. They are commonly found in soil, food, grains and cellulose. Some of the species can produce mycotoxins [8], [16]. The toxicity of the spores does not decrease even when the mould itself is already gone. Most of the species of the genus Penicillium are harmless to people with strong immune system [9], [16].

\section{CONCLUSION}

An experiment to investigate indoor air in straw bale and reed houses was carried out from October 2014-October 2016 in Northern part of Estonia. Samples were taken from 8 test houses.

Mean values of CFU were higher in reed houses. This is probably due the lack of good HVAC systems in two of four houses. There was also seasonal difference. Mean values were highest during summer months and lowest in winter. In spring and in autumn the values were in same range.

The genera of the identified fungi were Alternaria, Aspergillus, Penicillium and Cladosporium. Most of these species can present a health risk for humans, especially for those with allergies, asthma and weakened immune systems. Children and the elderly people 
will also be affected. If there will be any constant "flu-like" symptoms, it is highly recommended to consult the physician as soon as possible.

\section{REFERENCES}

[1] Goodhew, S., Griffiths, R. \& Woolley, T., An investigation of the moisture content in the walls of a straw-bale building. Building and Environment, 39(12), pp. 1443-1451, 2004.

[2] Milutiene, E., Jürmann, K. \& Keller, L., Straw bale building - reaching energy efficiency and sustainability in northern latitudes, 2010. Available online, www.earthzine.org/2010/04/26/straw-bale-building-\%E2\%80\%93-reaching-energyefficiency-and-sustainability-in-northern-latitudes/. Accessed on: 8 Jan. 2017.

[3] Paist, A., et al., Potential of biomass fuels to substitute for oil shale in energy balance in Estonian energy sector. Oil Shale, 22(4), pp. 369-379, 2005.

[4] Veski, R., Palu, V., Luik, H. \& Kruusement, K., Thermochemical liquefaction of reed. Proceedings of the Estonian Academy of Sciences: Chemistry, 54(1), pp. 45-56, 2005.

[5] Milutiene, E., Staniškis, J.K. \& Kručius, A., Increase in buildings sustainability by using renewable materials and energy. Clean Technologies and Environmental Policy 14(6), pp. 1075-1084, 2012.

[6] Kuhn, D.M. \& Ghannoum, M.A., Indoor mold, Toxigenic fungi, and Stachybotrys chartarum: Infectious disease perspective. Clinical Microbiology Reviews, 16(1), pp. 144-172, 2003.

[7] Chapman, M.D., Challenges associated with indoor moulds. Medical Mycology, 44, pp. 29-32, 2006.

[8] Singh, J., Allergic reactions: occupational hygiene. Health and Safety, pp. 14-16, 2000.

[9] Raamets, J., Kutti, S., Vettik, A., Ilustrumm, K., Rist, T. \& Ivask, M., The antimicrobial effect of three different chemicals for the treatment of straw bales used in housing projects. Proceedings of the International Conference on Sustainable Housing Planning, Management and Usability: Sustainable Housing 2016, pp. 537-545, 2016.

[10] Mędrela-Kuder, E., Seasonal variations in the occurrence of culturable air borne fungi in outdoor and indoor air in Craców. International Biodeterioration \& Biodegradation, 52, pp. 203-205, 2003.

[11] Haleem Khan, A.A. \& Mohan Karuppayil, S., Fungal pollution of indoor environments and its management. Saudi Journal of Biological Sciences, 19(4), pp. 405-426, 2012.

[12] Woodcock, A., Moulds and asthma: Time for indoor climate change? Thorax, 62(9), pp. 745-746, 2007.

[13] Sanchez, H. \& Bush, R.K., A review of Alternaria alternate sensitivity. Revista Iberoamericana de Micología, 18, pp. 56-59, 2001.

[14] de Hoog, G.S. \& Horre, R., Molecular taxonomy of the Alternaria and Ulocladium species from humans and their identification in the routine laboratory. Mycoses, $\mathbf{4 5}$, pp. 259-276, 2002.

[15] Ellis, M.E., Al-Abdely, H., Sandridge, A., Greer, W. \& Ventura, W., "Fungal endocarditis: Evidence in the world literature 1965-1995. Clinical Infectious Diseases, 32, pp. 50-62, 2001.

[16] Bennett, J.W. \& Klich, M., Mycotoxins. Clinical Microbiology Reviews, 16(3), pp. 497-516, 2003.

[17] Bensch, K., Braun, U., Groenewald, J.Z. \& Crous, P.W., The genus Cladosporium. Studies in Mycology, 72, pp. 1-401, 2012. 